\title{
SYNTHESIS AND COMPLETE NMR SPECTRAL ASSIGNMENTS OF NEW BENZYLAMINO COUMARIN DERIVATIVE
}

\author{
VIDOSLAV DEKIĆ ${ }^{*}$, NIKO RADULOVIĆ ${ }^{2}$ MILENKO RISTIĆ ${ }^{1}$, BILJANA DEKIĆ1, \\ NOVICA RISTIĆ ${ }^{1}$
}

${ }^{1}$ Faculty of Sciences, University in Priština - Kosovska Mitrovica, Kosovska Mitrovica, Serbia

${ }^{2}$ Department of Chemistry, Faculty of Sciences and Mathematics, University of Niš, Niš, Serbia

\begin{abstract}
This research involves the reaction of 4-chloro-3-nitrocoumarin and (4-methoxyphenyl)methanamine, whereby a novel coumarin derivative 4-[(4-methoxybenzyl) amino]-3-nitro-2H-chromen-2-one was obtained in good yield. The reaction was carried out in ethyl acetate, in the presence of triethylamine. Also, a detailed spectral analysis of a new coumarin derivative is presented. Resonance assignment was achieved using one- $\left({ }^{1} \mathrm{H}\right.$ NMR and ${ }^{13} \mathrm{C}$ NMR) and two-dimensional NMR techniques $\left({ }^{1} \mathrm{H}-{ }^{1} \mathrm{H}-\mathrm{COSY}\right.$, NOESY, HSQC, and HMBC). The NOESY correlations of protons from arylamino substituent and coumarin core indicate their spatial orientation.
\end{abstract}

Keywords: Coumarins, Synthesis, Spectral analysis, ${ }^{1} \mathrm{H}$ NMR, ${ }^{13} \mathrm{C}$ NMR, $2 \mathrm{D}$ NMR.

\section{INTRODUCTION}

Coumarins are important, naturally occurring heterocyclic compounds (Barry, 1964; Murray, 1989; O’Kennedy \& Thornes, 1997). Secondary metabolites occurring in plants include a large number of different groups of compounds. Coumarins represent one of them and they are found in all plant vegetative and reproductive organs, from root to seed. Their function is far from clear, but suggestions include the role of the waste products, plant growth regulators, fungistats and bacteriostats (Murray et al., 1982). Coumarins have long been recognized to possess antiinflammatory, anti-oxidant, anti-allergic, hepatoprotective, antithrombotic, anti-viral, anti-microbial and anti-carcinogenic activities (Jung et al., 2008). Many coumarin derivatives represent the compounds with an important role in the dyes industry. Also, they have characteristic properties that allow them to be used as optical brighteners, laser dyes, nonlinear optical chromophores, solar energy collectors, fluorescent labels and probes in biology and medicine, and two-photon absorption (TPA) materials (Turki et al., 2007; Li et al., 2007; Melavanki et al., 2008; Yu et al., 2009).

The bioactivities of coumarins are based on the influence of the coumarin nucleus, but a significant role in the pharmacological and biochemical properties of coumarins also depends on the pattern of substitution (Jiménez-Orozco et al., 1999; Finn et al., 2001). Due to their medicinal and physiological properties, coumarins have been intensively studied, and a large number of synthetic organic chemists emphasized their simplest and most efficient synthesis.

The physical and chemical properties of coumarins are well-known, but little attention has been paid to their properties in nuclear magnetic resonance. As a part of our continuing investigations about coumarins (Dekić et al., 2010; Dekić et al.,

* Corresponding author: vidoslav.dekic@ @r.ac.rs
2014), we report herein the synthesis of new coumarin derivative and complete assignments of his ${ }^{1} \mathrm{H}$ and ${ }^{13} \mathrm{C}$ NMR spectral data based on a combination of $1 \mathrm{D}$ and 2D NMR experiments.

\section{EXPERIMENTAL}

\section{Materials and methods}

Melting points were determined on a Kofler hot-plate apparatus and are uncorrected. HRMS(EI) spectra were recorded on a JEOL Mstation JMS 700 instrument (JEOL, Germany). Thermo Nicolet 6700 FTIR spectrophotometer was used for IR measurements. For TLC, silica gel plates (Kiesel 60 F254, Merck) were used. TLC plates were caused by spraying with aqueous sulfuric acid $(1: 1, v / v)$ and heating afterward. All solvents (HPLC grade) and other chemicals were purchased from Sigma-Aldrich (USA), Merck (Germany), and Fluka (Germany).

\section{NMR measurement}

All NMR spectra were recorded at $25{ }^{\circ} \mathrm{C}$ in DMSO- $d_{6}$ with TMS as an internal standard. Chemical shifts are reported in ppm $(\delta)$ and referenced to TMS $\left(\delta_{\mathrm{H}}=0 \mathrm{ppm}\right)$ in ${ }^{1} \mathrm{H}$ NMR spectra or to residual DMSO- $d_{5} /{ }^{13} \mathrm{CD}_{3} \mathrm{SOCD}_{3}\left(\delta_{\mathrm{H}}=2.50 \mathrm{ppm}, \delta_{\mathrm{C}}=39.52\right.$ $\mathrm{ppm}$ ) in heteronuclear 2D spectra. Scalar couplings are reported in Hertz.

The ${ }^{1} \mathrm{H}$ and ${ }^{13} \mathrm{C}$ NMR spectra of the synthesized compound were recorded on a Bruker Avance III $400 \mathrm{MHz}$ NMR spectrometer $\left({ }^{1} \mathrm{H}\right.$ at $400 \mathrm{MHz},{ }^{13} \mathrm{C}$ at $\left.100 \mathrm{MHz}\right)$, equipped with a 5 -mm dual ${ }^{13} \mathrm{C} /{ }^{1} \mathrm{H}$ probe head.

Synthesis

Synthesis of 4-chloro-3-nitrocoumarin (3)

The synthesis of 4-chloro-3-nitrocoumarin (3) was carried out according to a previously published procedure (Kaljaj et al., 1987). 4-Hydroxycoumarin (1) was nitrated with a mixture of 
$\mathrm{HNO}_{3}(72 \%)$ and glacial acetic acid to afford 4-hydroxy-3nitrocoumarin. The synthesis of the starting compound, 4-chloro3-nitrocoumarin (3) was carried out in the second reaction step by the following manner: $N, N$-dimethylformamide (DMF, $4 \mathrm{ml}$, $52 \mathrm{mmol}$ ) was cooled to $10{ }^{\circ} \mathrm{C}$ in an ice bath. With stirring, $\mathrm{POCl}_{3}(8.0 \mathrm{~g}, 52 \mathrm{mmol})$ was added dropwise, and the obtained mixture was stirred for an additional $15 \mathrm{~min}$. After the expiration of the estimated period time, the reaction was continued at room temperature for the next 15 minutes. Afterward, the solution of 4-hydroxy-3-nitrocoumarin (10.8 g; $52 \mathrm{mmol})$ in DMF (25 ml) was added dropwise and the obtained mixture was stirring for another 15 minutes. Finally, to stop the reaction, $30 \mathrm{ml}$ of icecold water was added. The precipitated solid was collected by filtration and washed with saturated sodium bicarbonate solution and water. Recrystallization from the mixture of benzene-hexane $(1: 1, v / v)$ yielded yellow crystals of 4-chloro-3-nitrocoumarin $(10.2 \mathrm{~g})$ in $87 \%$ yield, m.p $162-163^{\circ} \mathrm{C}$.

Synthesis of 4-[(4-methoxybenzyl)amino]-3-nitro-2H-chromen-2one (5)

The solution of 4-chloro-3-nitrocoumarin (3) (1 g, 4.4 mmol) and (4-methoxyphenyl)methanamine (4) (0.55 g, 4.4 $\mathrm{mmol})$ in ethyl acetate $(10 \mathrm{ml})$ was refluxed in the presence of triethylamine $(1 \mathrm{ml}, 7.2 \mathrm{mmol})$ for $3 \mathrm{~h}$. After cooling, the precipitated solid was filtered off and washed with ethyl acetate and water. The flow of reaction was monitored by TLC. The target product, 4-[(4-methoxybenzyl)amino]-3-nitro- $2 \mathrm{H}$ chromen-2-one (5), was obtained as a pale yellow powder, m.p. 194-196 ${ }^{\circ} \mathrm{C}$, in very good yield - 78\%. HRMS(EI): $\mathrm{M}^{+}$ $\left(\mathrm{C}_{17} \mathrm{H}_{14} \mathrm{~N}_{2} \mathrm{O}_{5}\right)$ 326.0915, requires $326.0903(\Delta=+1.2 \mathrm{mmu})$. IR (neat): $3344(\mathrm{~N}-\mathrm{H}), 3083$ (Ar-H), 2940 and $2845(\mathrm{C}-\mathrm{H}), 1681$ $(\mathrm{C}=\mathrm{O}), 1607(\mathrm{C}=\mathrm{C}), 1515$ and $1335\left(\mathrm{NO}_{2}\right), 1176,1026,914$, $815,738 \mathrm{~cm}^{-1}$.

\section{RESULTS AND DISCUSSION}

\section{Chemistry}

The target compound, 4-[(4-methoxybenzyl)amino]-3nitro- $2 \mathrm{H}$-chromen-2-one (5), were prepared in the reaction of 4 chloro-3-nitrocoumarin (3) and (4-methoxyphenyl)methanamine (4) in ethyl acetate in the presence of two equivalents of triethylamine. The product was obtained in a good yield of $78 \%$ (Scheme 1). The structure of the synthesized compound was confirmed by spectral means (HRMS(EI), IR, ${ }^{1} \mathrm{H}$ and $\left.{ }^{13} \mathrm{C} N M R\right)$.<smiles>O=c1cc(O)c2ccccc2o1</smiles>

1<smiles></smiles>

3<smiles>COc1ccc(CNc2c([N+](=O)[O-])c(=O)oc3ccccc23)cc1</smiles>

Scheme 1. Synthesis of 4-[(4-methoxybenzyl)amino]-3-nitro-2H-chromen-2-one.

High-resolution electron impact mass spectrometry (HREIMS) of synthesized compound indicated a molecular formula of $\mathrm{C}_{17} \mathrm{H}_{14} \mathrm{~N}_{2} \mathrm{O}_{5}\left([\mathrm{M}]^{+}\right.$at $\mathrm{m} / z$ 326.0915, $\left.\Delta=+1.2 \mathrm{mmu}\right)$. The IR spectra contained characteristic vibrations of the $\mathrm{Ar}-\mathrm{H}$ and $\mathrm{N}-\mathrm{H}$ bonds at 3083 and $3344 \mathrm{~cm}^{-1}$, respectively. The strong band at $1681 \mathrm{~cm}^{-1}$ corresponding to absorptions of the $\mathrm{C}=\mathrm{O}$ bond. The IR absorptions due to the presence of the $\mathrm{NO}_{2}$ group appeared at 1335 and $1515 \mathrm{~cm}^{-1}$.

The ${ }^{1} \mathrm{H}$ NMR spectrum of synthesized compound exhibited six aromatic methine signals, four sets of doublet of doublets at
8.36, 7.41, 7.23 and $6.91 \mathrm{ppm}$ and two sets of doublet of doublet of doublets at 7.74 and $7.45 \mathrm{ppm}$. The NOESY correlations differentiated two separate proton spin systems (Figure 1). The first spin system comprised four signals, two sets of doublet of doublets at 8.36 and $7.41 \mathrm{ppm}$, and two sets of doublet of doublets of doublets at 7.74 and $7.45 \mathrm{ppm}$, while the second spin system contains two sets of doublet of doublets at 7.23 and 6.91 ppm.

The number of resonances suggests that a group of four signals belongs to the protons of coumarin moiety. Additionally, 
integration of the ${ }^{1} \mathrm{H}$ NMR spectra shows the double intensity of signals at 7.23 and $6.91 \mathrm{ppm}$ and assigns them to chemically equivalent protons in the positions of $\mathrm{H}-3^{\prime} / 7^{\prime}$, and $\mathrm{H}-4^{\prime} / 6^{\prime}$. The assignment of these two groups of signals is provided due to NOESY correlation of broad range singlet at $9.01 \mathrm{ppm}$, assigned to the proton of the secondary amino group. This signal showed the cross peak with the signal at $8.36 \mathrm{ppm}$, which assigns H-5. The rest protons bounded to the coumarin core were easily assigned based on their mutual NOESY interactions (Figure 1, Table 1). The mentioned proton of the secondary amino group in the same spectrum showed two more interaction, with the signals at 4.42 and $7.23 \mathrm{ppm}$. According to chemical shift and integral (corresponding to two protons) from ${ }^{1} \mathrm{H}$ NMR, the signal at 4.42 ppm is attributed to two methylene protons. The simultaneous interaction of the doublet of doublets at $7.23 \mathrm{ppm}$ with the signals of $\mathrm{N}-\mathrm{H}$ and methylene protons assigned the two equivalent protons which occupy positions $3^{\prime}$ and $7^{\prime}$ on the substituent ring. The remaining aromatic protons $\left(\mathrm{H}-4^{\prime}\right.$ and $\left.\mathrm{H}-6^{\prime}\right)$ was assigned to the signal at $6.91 \mathrm{ppm}$, which was confirmed by its interaction with the last signal in the ${ }^{1} \mathrm{H}$ NMR at $3.75 \mathrm{ppm}$ attributed to methoxy protons.

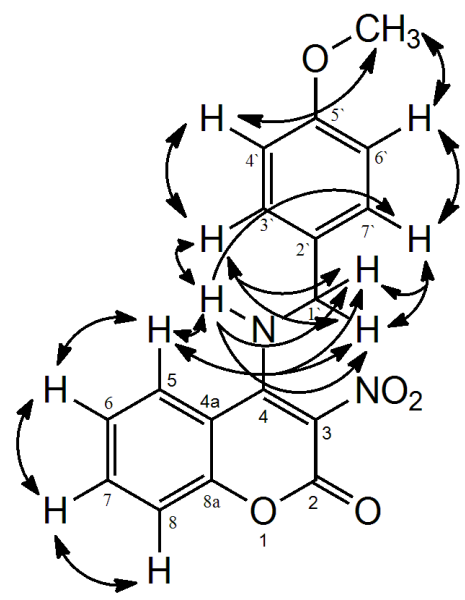

Figure 1. The NOESY correlations of 4-[(4-methoxybenzyl) amino]-3-nitro-2 $H$-chromen-2-one.

The chemical shift of carbon atoms to which these protons were bonded was subsequently determined from the HSQC spectrum (Table 1). The assignment of these protons and carbons was additionally supported through the corresponding $\mathrm{HMBC}$ correlations (Figure 2).

The quaternary carbons $\mathrm{C}-4 \mathrm{a}$ and $\mathrm{C}-8 \mathrm{a}$ were assigned according to $\mathrm{HMBC}$ spectrum data. Existence of simultaneous interactions of protons $\mathrm{H}-6$ and $\mathrm{H}-8$ with the carbon signal at $114.7 \mathrm{ppm}$, as well as H-5 and H-7 with the signal at $151.4 \mathrm{ppm}$, assigns $\mathrm{C}-4 \mathrm{a}$ and $\mathrm{C}-8 \mathrm{a}$, respectively.

Also, in HMBC spectrum is observed a characteristic interaction through two bonds between $\mathrm{H}-8$ and the quaternary C-8a, similar to the previously studied compounds (Dekić et al. 2010, 2014). Additionally, H-5 showed through three bonds interactions with the signal at $147.7 \mathrm{ppm}$, attributed to quaternary carbon $\mathrm{C}-4$. On the other hand, C-4 showed a cross peak with the methylene protons signal at $4.42 \mathrm{ppm}$, which confirms the existence of the amino bridge and position of substituent on the coumarin core. The HMBC correlations between proto resonance of the secondary amino group $(9.01 \mathrm{ppm})$ and carbon atom at 116.6 ppm, assigned C-3.

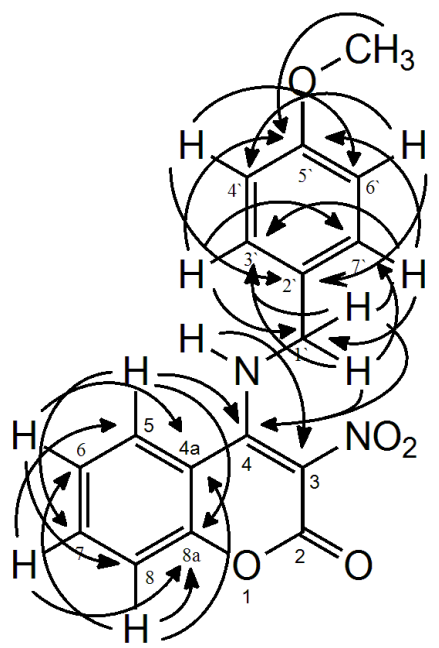

Figure 2. The HMBC correlations of 4-[(4-methoxybenzyl) amino]-3-nitro-2 $H$-chromen-2-one.

Table 1. NMR data of compound (5) in DMSO- $d_{6}$.

\begin{tabular}{|c|c|c|c|c|}
\hline Position & $\delta_{\mathrm{H}}, \mathrm{m}(J, \mathrm{~Hz})$ & $\delta_{\mathrm{C}}$ & NOESY $^{\mathrm{a}}$ & $\mathrm{HMBC}^{\mathrm{b}}$ \\
\hline 2 & & 155.6 & & \\
\hline 3 & & 116.6 & & \\
\hline 4 & & 147.7 & & \\
\hline $4 a$ & & 114.7 & & \\
\hline 5 & $\begin{array}{c}8.36 \mathrm{dd} \\
(8.4,1.2)\end{array}$ & 124.8 & $6,1^{\prime}, \mathrm{N}-\underline{\mathrm{H}}$ & $7,4,8 \mathrm{a}$ \\
\hline 6 & $\begin{array}{c}7.45 \text { ddd } \\
(8.4,7.2,0.8)\end{array}$ & 125.1 & 5,7 & $4 a, 8$ \\
\hline 7 & $\begin{array}{c}7.74 \text { ddd } \\
(8.4,7.2,1.2)\end{array}$ & 134.5 & 6,8 & $5,8 \mathrm{a}$ \\
\hline 8 & $\begin{array}{c}7.41 \mathrm{dd} \\
(8.4,0.8)\end{array}$ & 117.9 & 7 & $4 a, 6,8 a$ \\
\hline $8 a$ & & 151.4 & & \\
\hline $\mathrm{N}-\mathrm{H}$ & 9.01 brs & & $5,1^{\prime}, 3^{\prime} / 7^{\prime}$ & 3 \\
\hline $1^{\prime}$ & $\begin{array}{c}4.42 \mathrm{~d} \\
(5.2)\end{array}$ & 48.1 & $\begin{array}{c}5,3^{\prime} / 7^{\prime}, \\
\text { N-H }\end{array}$ & $3^{\prime} / 7^{\prime}, 4$ \\
\hline 21 & & 128.7 & & \\
\hline $3^{\prime} / 7^{\prime}$ & $\begin{array}{c}7.23 \mathrm{dd} \\
(6.8,2.0)\end{array}$ & 129.3 & $\begin{array}{c}1^{\prime}, 4^{\prime} / 6 ', \\
\text { N-H }\end{array}$ & $3^{\prime} / 7^{\prime}, 5^{\prime}, 1^{\prime}$ \\
\hline $4^{\prime} / 6^{\prime}$ & $\begin{array}{c}6.91 \mathrm{dd} \\
(6.8,2.0)\end{array}$ & 114.5 & $3^{\prime} / 7^{\prime}, 8^{\prime}$ & $2^{\prime}, 4^{\prime} / 6^{\prime}$ \\
\hline 51 & & 159.4 & & $\mathrm{C}-2^{\prime}$ \\
\hline 81 & $3.75 \mathrm{~s}$ & 55.6 & $4^{\prime} / 6^{\prime}$ & $5^{\prime}$ \\
\hline
\end{tabular}

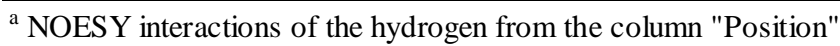
with the corresponding hydrogen from the column "NOESY".

${ }^{\mathrm{b}} \mathrm{HMBC}$ interactions of the hydrogen from the column "Position" with the corresponding carbons from the column "HMBC". 
The remaining carbon of the substituent side group was assigned at $159.4 \mathrm{ppm}$, trough cross-peaks of this signal and signals at $7.23 \mathrm{ppm}\left(\mathrm{H}-3^{\prime}\right.$ and $\left.\mathrm{H}-7^{\prime}\right)$ and $3.75 \mathrm{ppm}$ (methoxy protons) observed in the HMBC spectrum. Finally, the last carbon signal at $155.6 \mathrm{ppm}$ was attributed to the lactone carbonyl (C-2) based on their chemical shifts, since no $\mathrm{H}$ interactions were observed in any 2D spectra and by comparison with the analogous signals in related compounds (Dekić et al., 2010; Dekić et al., 2014).

The mutual spatial relation between the coumarin core and arylamino substituent (Figure 3) can be ascertained from proton NOESY interactions. The correlations of H-5 with methylene hydrogens and N-H proton in the NOESY spectrum suggest that the coumarin core and secondary amino group are not in the same plane but rather are at an angle to one another. On the other side, the proton of the secondary amino group showed through space interactions with H-3` and/or H-7`. The abovementioned cross-peaks suggest that the substituent ring is oriented away from the coumarin framework. Simultaneous correlations of H-5 with methylene hydrogens and $\mathrm{N}-\mathrm{H}$ proton, as well as a mentioned proton of the amino group with $\mathrm{H}-3$ ' and H-7' cannot appear in a single conformation of the molecule, but may result from single-bond rotation around the $\mathrm{C} 4-\mathrm{N}$ in the first, and $\mathrm{N}$ $\mathrm{C} 1$ and $\mathrm{C} 1-\mathrm{C} 2$ in the second proton interaction giving rise to different conformations that are close in energy (this was confirmed by energy minimization calculations using MM2 force field from the ChemDraw 11.0 software package).

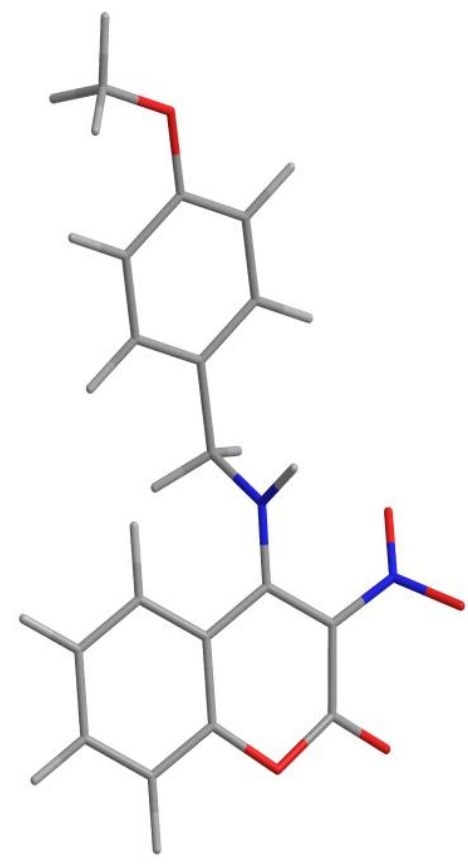

Figure 3. Spatial orientation of coumarin core and arylamino substituent in the molecule of 4-[(4-methoxybenzyl)amino]-3nitro-2H-chromen-2-one.

\section{CONCLUSION}

In a nutshell, this research is presented synthesis and detailed spectral characterization of a new coumarin derivative 4[(4-methoxybenzyl)amino]-3-nitro-2H-chromen-2-one. The spectral assignment was performed by combining $1 \mathrm{D}-\left({ }^{1} \mathrm{H}\right.$ NMR and ${ }^{13} \mathrm{C}$ NMR) and 2D-NMR techniques $\left({ }^{1} \mathrm{H}-{ }^{1} \mathrm{H}-\mathrm{COSY}\right.$, NOESY, HSQC, and HMBC). NOESY correlations of protons of the arylamino substituent and the coumarin moiety indicate their mutual spatial orientation.

\section{ACKNOWLEDGMENTS}

Financial support for this study was granted by the Ministry of Education, Science and Technological Development of Serbia [Project No. 172061 and 45022].

\section{REFERENCES}

Barry, R. D. 1964. Isocoumarins. Developments science 1950. Chemical Reviews, 64(3), pp. 229-260. doi: 10.1021/cr60229a002

Dekić, V., Dekić, B., \& Radulović, N. 2013. ${ }^{1} \mathrm{H}$ and ${ }^{13} \mathrm{C}$ NMR spectral assignments of an amino acid-coumarin hybrid. Facta Universitatis Series: Physics, Chemistry and Technology, 11(3), pp. 101-107. doi: 10.2298/fupct1301101d

Dekić, V., Radulović, N., Vukićević, R., Dekić, B., Skropeta, D., \& Palić, R. 2010. Complete assignment of the ${ }^{1} \mathrm{H}$ and ${ }^{13} \mathrm{C}$ NMR spectra of antimicrobial 4-arylamino-3-nitrocoumarin derivatives. Magnetic Resonance in Chemistry, 48(11), pp. 896-902. doi: $10.1002 / \mathrm{mrc} .2681$

Finn, G. J., Creaven, B., \& Egan, D. A. 2001. Study of the in vitro cytotoxic potential of natural and synthetic coumarin derivatives using human normal and neoplastic skin cell lines. Melanoma Research, 11(5), pp. 461-467. doi: 10.1097/00008390-200110000-00004

Jiménez-Orozco, F. A., Molina-Guarneros, J. A., MendozaPatiño N., León-Cedeño, F., Flores-Pérez, B., Santos-Santos, E., \& Mandoki, J. J. 1999. Cytostatic activity of coumarin metabolites and derivatives in the B16-F10 murine melanoma cell line. Melanoma Research, 9(3), pp. 243-247. doi: 10.1097/00008390-199906000-00005

Jung, K., Park, Y. J., \& Ryu, J. S. 2008. Scandium(III) TriflateCatalyzed Coumarin Synthesis. Synthetic Communications, 38(24), pp. 4395-4406. doi: 10.1080/00397910802369513

Kaljaj, V., Trkovnik M., \& Stefanović-Kaljaj, L. 1987. Syntheses of new heterocyclocoumarins starting with 3-cyano-4chlorocoumarin. Journal of the Serbian Chemical Society, 52(4), pp. 183-185.

Li, X., Zhao, Y. X., Wang, T., Shi, M. Q., \& Wu, F. P. 2007. Coumarin derivatives with enhanced two-photon absorption cross-sections. Dyes Pigments, 74(1), pp. 108-112. doi: 10.1016/j.dyepig.2006.01.020

Melavanki, R. M., Kusanur, R. A., Kulakarni, M. V., \& Kadadevarmath, J. S. 2008. Role of solvent polarity on the fluorescence quenching of newly synthesized 7,8-benzo-4azidomethyl coumarin by aniline in benzene-acetonitrile mixtures. Journal of Luminescence, 128(4), pp. 573-577. doi: 10.1016/j.jlumin.2007.08.013 
Murray, R. D. H. 1989. Coumarins. Natural Product Reports, 6, pp. 591-624.

Murray, R. D. H., Mendez, J., \& Brown, S. A. (1982) The Natural Coumarins: Occurrence, Chemistry and Biochemistry. New York: Wiley \& Sons.

O’Kennedy, R., \& Thornes, R. D. (1997) Coumarins - Biology, Applications and Mode of Action. Chichester: John Wiley \& Sons.
Turki, H., Abid, S., Fery-Forgues, S., \& El Gharbi, R. 2007. Optical properties of new fluorescent iminocoumarins: Part 1. Dyes Pigments, 73(3), pp. 311-316. doi: 10.1016/j.dyepig.2006.01.001

Yu, T., Zhang, P., Zhao, Y., Zhang, H., Meng, J., \& Fan, D. 2009. Synthesis and photoluminescent properties of two novel tripodal compounds containing coumarin moieties. Spectrochimica Acta Part A: Molecular and Biomolecular Spectroscopy, 73(1), 168-173. doi: 10.1016/j.saa.2009.02.013 